\title{
EMPING MADE OF CASSAVA IN SUKYAMAI VILLAGE SUB- DISTRICT PULO BANDRING DISTRICT ASSAHAN
}

\author{
Eko Wahyu Nugrahadi ${ }^{1 *}$, Sahat Siagian ${ }^{2}$, Wahyu Tri Atmojo ${ }^{3}$ \\ ${ }^{1}$ Department of Bussiness Administration Education, Faculty of Economics, Medan State University, Medan, \\ Indonesia \\ ${ }^{2}$ Electro Major, Faculty of Engineering, Medan State University, Medan, Indonesia \\ ${ }^{3}$ Fine Arts Education Major, Faculty of Languages and Arts, Medan State University, Medan, Indonesia \\ *Corresponding Author: ewahyunugrahadi@yahoo.com
}

\begin{abstract}
Grated chips business developed by Mr. Bakri and Mrs. Armawati in Sukadamai Village Pulo Bandring District is still less developed and needs to be assisted. The process of grated chips production is still constrained by the low skills or innovation of processed products made from cassava produced. The two partners only make the grate, while the competition for this business continues to increase. Each day the chips grated production of these partners business can produce a total of $60 \mathrm{~kg} /$ day or 56 packs of grated chips. Beside that, there is still modern markets demand or cake shops that can not be fulfilled due to the lack of knowledge of partners about innovative products based on cassava and packaging design. In relation to the problems faced by both partners, Pak Bakri and Mrs. Armawati, then in the program of dedication to the community in accordance with the agreement of both partners have been planned and realized the existence of training and production simulation by making new products in the form of emping based sweet potato that can be produced by these two partners with total $90 \mathrm{~kg} /$ day or 120 packs/day using a cassava grinder. It also planned the procurement of packaging design tools to assist marketing programs in the fulfillment consumer demand of modern market or cake shops. The purpose of all these activities is to maintain the continuity of business or continuity of grated chips business developed by Mr. Bakri and Mrs. Armawati in Sukadamai Village Pulo Bandring sub-district. The success rate of this devotion program to community has been completed, such as: 1 . There is a new product that can be produced by the business of Mr. Bakri and Mrs. Armawati, 2. The existence of cassava grinder, 3. The existence of packaging design tools, 4. The existence of packaging design.
\end{abstract}

Keywords: Product Innovation, Emping made of Cassava, Packaging Design

\section{PREFACE}

Asahan regency is one of the regencies that located in the East Coast region of North Sumatra Province, with the total area of 373,297 ha, the administrative area of the Asahan Regency Government consists of 25 sub-districts, 177 Villages and 25 urban Villages with different areas. The agricultural sector is a sector that has a strategic role in the structure of economic development in Asahan Regency which is divided into two types of plantations, namely small holders plantation and large plantation. Smallholder plantation is plantation that managed directly by the community, with the dominant food crops in Asahan Regency are rice, corn, cassava and soybeans. Cassava plant is cultivated in almost all sub-district except Sei Kepayang Timur, Tanjung Balai and Air Joman. Pulo Bandring subdistrict with an area of $82.78 \mathrm{~km} 2$ has a cassava plantation with an area of 15 hectares and is able to produce 25.075 $\mathrm{kg}$ of cassava per year.

Sukadamai Village is one of the villages located in Pulo Band Ring sub-district with lowland topography which has of cassava fields big enough about 9 ha. With the potential of cassava field, making some part of people in the village of Sukadamai to make a variety of food snacks with raw materials of cassava. One of them is micro business owned by Mr. Muhammad Bakri and Mrs. Armawati. The type of business that developed by micro-entrepreneur is grated chips made from cassava. Mr Bakri's micro business has been developed hereditary. While Mrs Armawati's micro venture is education and training given by Mr Muhammad Bakri which at the time the demand for the grated chips is greatly increased to fulfill the market demand.

High competition and many micro-business of grated chips make micro-business of these two partners are very difficult to expand the market, so therefore it is necessary to do product innovation so that sales can be increased. 
From the aspect of production, each business group performs the production process located at his home. Each group starts to work from 8 am to $4 \mathrm{pm}$. There are 5 workers in each group, 1 person will get a part to market the product and 4 people will do the production process starts from the selection of cassava to the packaging process of grated chips. Each day the group of partners is able to manage cassava as much as $30 \mathrm{~kg}$ by producing 28 packs and each pack contains 20 pieces of grated chips, per pack is given the price of Rp. 10.000, -. Meanwhile, the product innovation will be able to produce cassava as much as $45 \mathrm{~kg}$ per day by producing 50 packs of cassava chips, per packet is given the price of Rp. 10,000, - with the expectation of product innovation can expand the market of both partners. The following are the stages of grated chips production conducted by both partners and the production process that has been done as follows:

1. cassava peeled and then wash thoroughly, then cassava is shredded with grater of coconut that modified.

2. then mix the cassava with the spices that have been prepared and mix well.

3. print the dough with a simple mould, then grated chips along with the mould are steamed for 15 minutes until cooked.

4. the steamed that has been cold is then released from the mould and grated chips can be dried for 4-5 hours.

5. the crispy chips that have dried can be do the frying process.

6. the grated chips that have fried then will do the simple packaging.

During this time both partners sell the grated chips by way of entrusted in small stalls of rural areas Pulo Bandring, Bunut Seberang, Suka Damai, Suka Damai Barat, Tanah Rakyat, Suka Makmur, Taman Sari, and Tanah Rakyat. Due to the increasingly high competition among micro small medium enterprises group, caused in every entrusted place or stalls of grated chips products owned by the two partners, there are other competitors of grated chips business that have the same production. The packaging of products by these two partners is also still simply so that the product is impressed does not hygienic. Therefore, this program is conducted to improve the skills of partners in the innovation of cassava products into crispy chip cassava with attractive packaging so that the superior products of partners can compete with other competitors and even can expand the market to various cake shops and modern market/supermarket.

The grated chips business owned by Mr. Muhammad Bakri and Mrs. Armawati in Sukadamai Village, Pulo Bandring sub-district is still done simply. Bookkeeping and financial statement and calculation of the cost of principal production of these two partners are not performed. This is because the level knowledge of that business partners have still minimal. Therefore, partners are very difficult to determine the profit earned each month.

Based on the existing conditions of these two partners, the issues that are found and mutually agreed with both partners can be seen in the table below.

Table 1.1. The Problems that Faced by Partners I (Mr. Bakri)

\begin{tabular}{|c|c|}
\hline Production Management & Marketing Management \\
\hline $\begin{array}{l}\text { - Production of } 30 \mathrm{~kg} / \mathrm{day} \text {, while the } \\
\text { demand reached } 45 \mathrm{~kg} / \mathrm{day} \text {. } \\
\text { The minimize of product } \\
\text { innovation level, so that difficult to } \\
\text { fulfill the demand and expansion } \\
\text { of market share } \\
\text { - Doesn't do production cost } \\
\text { calculations. }\end{array}$ & $\begin{array}{l}\text { The packaging design is so simple } \\
\text { that it is difficult to expand market } \\
\text { share and fulfilment the consumer } \\
\text { demand. } \\
\text { - Doesn't use design tool (bag sealer) }\end{array}$ \\
\hline Financial Management & Human Resource Management \\
\hline $\begin{array}{l}\text { - Bookkeeping / Financial Statement } \\
\text { are not performed }\end{array}$ & $\begin{array}{l}\text { - The level of skills in product } \\
\text { innovation is still low. } \\
\text { - Doesn't have skills in product design } \\
\text { - Doesn't know in calculation of } \\
\text { production costs and preparation of } \\
\text { financial statement }\end{array}$ \\
\hline
\end{tabular}

Source: Partner I (Mr. Bakri)

Table 1.2. The Problems That Faced By Partner II (Mrs. Armawati)

\begin{tabular}{|l|l|}
\hline Production Management & \multicolumn{2}{|l|}{ Marketing Management } \\
\hline $\begin{array}{l}\text { Production of } 30 \mathrm{~kg} / \mathrm{day} \text {, while the } \\
\text { demand reached } 45 \mathrm{~kg} / \text { day. }\end{array}$ & $\begin{array}{l}\text { The packaging design is so simple } \\
\text { that it is difficult to expand market }\end{array}$ \\
\hline
\end{tabular}




\begin{tabular}{|l|l|}
\hline $\begin{array}{l}\text { - The minimize of product } \\
\text { innovation level, so that difficult to } \\
\text { fulfill the demand and expansion } \\
\text { of market share } \\
\text { Doesn't do production cost } \\
\text { calculations. }\end{array}$ & $\begin{array}{l}\text { share and fulfilment the consumer } \\
\text { demand. } \\
\text { Doesn't use design tool (bag sealer) }\end{array}$ \\
\hline Financial Management & Human Resource Management \\
\hline $\begin{array}{l}\text { Bookkeeping / Financial Statement } \\
\text { are not performed }\end{array}$ & - $\begin{array}{l}\text { The level of skills in product } \\
\text { innovation is still low. } \\
\text { Doesn't have skills in product design } \\
\text { Doesn't know in calculation of } \\
\text { production costs and preparation of } \\
\text { financial statement }\end{array}$ \\
\hline
\end{tabular}

Source: Partner II (Mrs. Armawati)

Refers to table 1.1 and table 1.2 above relating with the problems of partners, specifically there are some obstacles and problems in the grated chips business owned by Mr Muhammad Bakri and Mrs Armawati in Sukadamai Village, Pulo Bandring sub-district which can be described as follows:

a. The absence of product innovation so that's difficult to expand the market and fulfilment the customer demand.

b. The grated chips product doesn't have labels and unattractive packaging.

c. Production management system and financial are conducted with estimates and habits so that the loss and profit can't be determined.

\section{RESULTS AND DISCUSSION}

There are some process on implementation activities of program crispy chips made of cassava in the Village Sukadamai Pulo Bandring sub-district Asahan as follows:

1. Education and Business Management Training

This education and training activity was conducted on July 7, 2017. The process activities, namely:

a.) Awarding of materials on the management of small and medium enterprises in a simple way starts from the group stewardship of grated chips business or human resources management, production management about how to determine the cost of production and marketing strategy.

2. Production Practice and Usage Of Tool

- Education and First Phase Of Training

This educational and training activity was conducted on July 8, 2017. The process of activities, namely:

a) Awarding of materials about healthy and hygienic crispy chips processing.

b) Awarding of the grinder tool of steamed cassava.

c) The practices of use of the grinder tool of steamed cassava are accordance with the tool operating procedures.

At this stage, it is hoped that the business group of grated chips can produce $40 \mathrm{~kg}$ of crispy chips per day and keep pay attention to the quality of the crispy chips. Here is the documentation of program activities in the first phase of training.
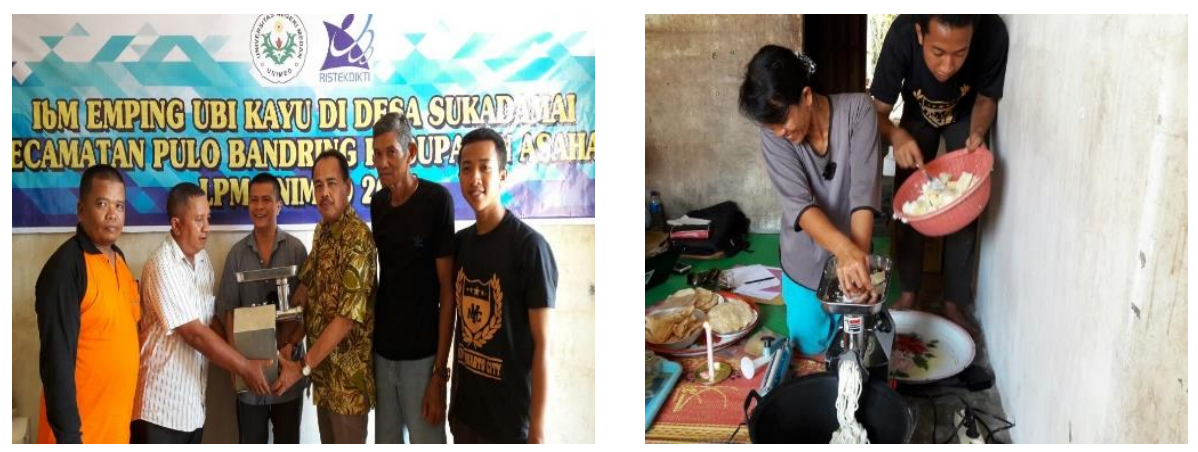

- Education and Second Phase Of Training

The next educational and training activity was conducted on July 15, 2017. The process of activities, namely: a) Evaluation of the first phase of education and training activities, by looking at the quality of the crispy chips cassava, the care of grinder tool of cassava, and the bookkeeping on the increased production and sales that happened. 
b) The incremental arising from the usage of such tools. Before using the tool, the crispy chip cassava business group is only able to produce $30 \mathrm{~kg}$ per day with an income of $\mathrm{Rp}$. 280,000. After using the tool, the group of grated chips business is able to produce $45 \mathrm{~kg}$ per day with an income of Rp. 500,000.

Based on the evaluation results that has conducted in the second stage of training, it can be known that the cassava slicer provides significant benefits and can increase the income of the grated chips business. Here is documentation of program activities in the second phase of training.
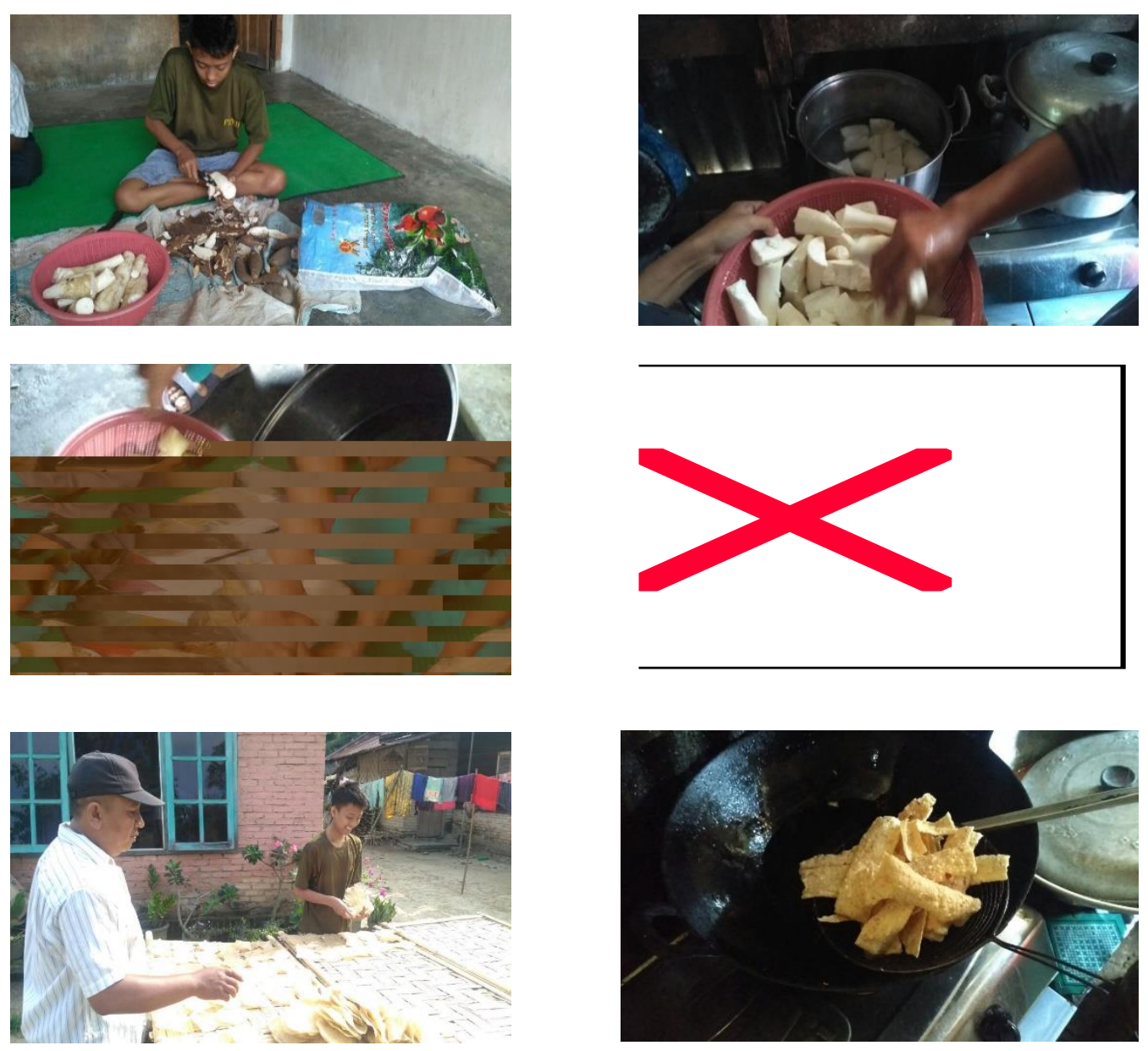

3. Education and Training of Product Design and Packaging

- Education and First Phase Of Training

This educational and training activity was conducted on July 21, 2017. The process of activities, namely:

a) Awarding of materials about how to design product packaging of crispy chips made from cassava appropriately, nice and looks interesting with lecture method, question and answer and product design practice.Awarding of the grinder tool of steamed cassava.

b) Awarding of the grinder packaging tool (bag sealer).

c) Awarding the packaging tool (bag seller). The practices of use the packaging tool (bag sealer) are accordance with the tool operating procedures.

At this stage is expected that the business group of grated chips can design the processed products as attractive as possible to increase the consumer interest to consume.

- Education and Second Phase Of Training

The next educational and training activity was conducted on July 22, 2017. The process of activities, namely:

a) Evaluation at education activities and the first phase of training by looking at packaging design, tool usage process and chips resistance using bag sealer tool.

b) Awarding of materials on how to market products through the use of information technology and social media in improving the marketing of grated chips products or establish partnerships with minimarket in Kisaran City. 
Here are some pictures the product of grated chips business that has packaged.
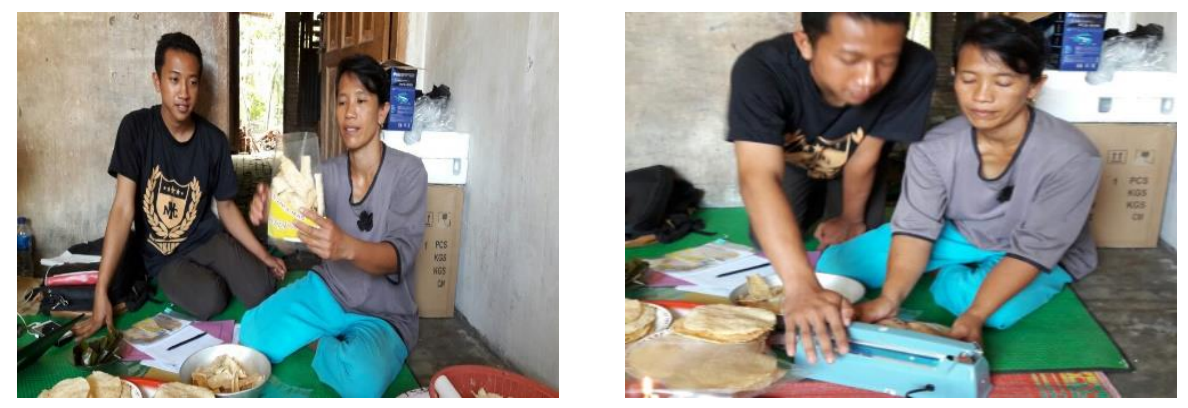

4. Education and Training Of Financial Report Preparation

This educational and training activity was conducted on July 29, 2017. Before entering the training, firstly evaluation of production training should be doing, tool-usage practices and packaging. Then continoud to practices of Financial Report preparation. The process of activities, namely:

a) Awarding materials about bookkeeping and making of financial report simply with lecture method, question and answer and practice.

b) Bookkeeping practices and financial reports based on the transactions occurring in the Business Group activities of Grated chips.

c) Awarding the duties to group members about how to make bookkeeping and financial statement according to the Business Group operational of Grated chips. With this duties are expected the next meeting in the mentoring process can be evaluated on the development of bookkeeping systems and financial statement of Grated chips Business Group.

Here is the documentation of educational activities and preparation training of financial statement.

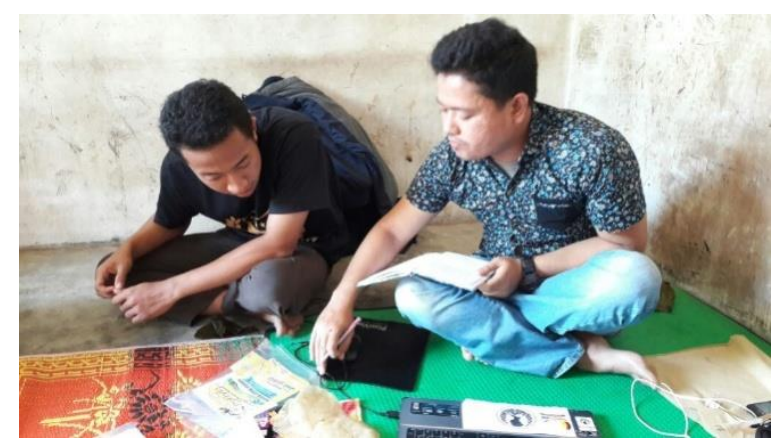

All processes of the activity can work well although there are obstacles in the process of understanding the Group members material of grated chips business of these two partners so the completion can't be so fast.

\section{CONCLUSION}

Based on the activities that have been implemented, it can be concluded that the IbM program activities of crispy chips made on cassava in Sukadamai Village, Pulo Bandring sub-district, Asahan District have been conducted, there are education and business management training, production practice and tool usage, education and marketing management training and packaging design, education and training of financial statement preparation.

It is hoped that such programs will continue and become the attention of government to assist small business actors to resolve the problems faced in their business operational, so that the small business group that whos has gived the fostering is able to be economically independent and can help the government program to assist in the resolve of the poverty level and unemployment in Indonesia. 